\title{
Purification and Characterization of Linamarase from Lactobacillus Plantarum
}

\author{
Adeleke BS*, Akinyele BJ and Olaniyi 00 \\ Department of Microbiology, Federal University of \\ Technology, Akure, Ondo State, Nigeria \\ *Correspondling author: Adeleke BS, Department of \\ Microbiology, Federal University of Technology, Akure, \\ Ondo State, Nigeria
}

Received: January 18, 2017; Accepted: March 07, 2017; Published: March 13, 2017

\begin{abstract}
In this study, bacteria isolated from fermenting bitter cassava peels were harnessed for linamarase production using standard microbiological procedures. Out of all the screened bacterial isolates, Lactobacillus plantarum exhibited highest linamarase activity and specific activity of $239.65 \mu \mathrm{mol} / \mathrm{min} / \mathrm{ml}$ and $43.57 \mu \mathrm{mol} / \mathrm{min} / \mathrm{mg}$ respectively. The linamarase was purified using DEAE Sephadex A-50 ion exchange chromatography and Sephadex G-150 column size exclusion or gel filtration chromatograpghy. A pH 6.0 was optimum for purified linamarase activity and relatively stable between 100 and 120 minutes. At $50 \mathrm{oC}$, optimum temperature was reached and linamarase activity maintained at $65 \%$ temperature stability between 40 to 60 minutes. The incubation of linamarase enzyme with $\mathrm{Ca}$ and $\mathrm{Mg}$ ions enhanced linamarase activity, while $\mathrm{Zn}$, $\mathrm{Fe}$ and $\mathrm{Cu}$ ions caused linamarase inhibition. The fact that purified linamarase from $\mathrm{Lb}$. planatrum was active at moderate temperatures and wide range of $\mathrm{pH}$ can suggests its applications as detoxifying agent in food industries for animal feed formulation where extreme conditions are required.
\end{abstract}

Keywords: Lactobacillus plantarum; Linamarase activity; $\mathrm{pH}$; Temperature stability

\section{Introduction}

Linamarin is a pro-carcinogenic substance found mostly in the leaves, peels and roots of some plants such as cassava, lima beans, flax etcetera in the family compositae, euphorbiaceae, linaceae, papaveraceae and fabaceae [1]. The presence of this toxic substance in some edible parts of plants limit its use as common source of foods to man. An insufficient food processing on consumption of underprocessed cassava roots containing linamarin above the safe level can result in upper motor neuron disease known as Konzo [2]. The toxicity is believed to be induced on ingestion of acetone cyanohydrin, the product from breakdown of linamarin. Hydrogen cyanide can be produced by hydrolytic reaction catalyzed by one or more enzymes from the plants containing cyanogenic glycosides when seeds are crushed, macerated, cut or mashed by traditional method [3]. The activities of linamarase-producing microorganisms in fermentation medium has contributed to the increase in the nutritive value, aroma, prolong shelf life, palatability of such product thereby ensuring food safety [4]. The traditional methods such as blanching and other methods have also contributed to the improvement in the palatability of such product thereby inhibiting the enzymatic reaction and prolong food shelf life.

Linamarase (EC.3.2.1.21) is a linamarin degrading enzyme, which on hydrolysis breaks down the glycolytic bond between $\beta$-glucose molecule and the chiral carbon atom linked to the nitrile group of linamarin present in cassava [5]. The application of this enzyme is limited because it is sensitive to environmental factors such as $\mathrm{pH}$ and temperature [6]. Over the years, humans have realized that selective propagation of animals and plants of desirable traits can improve and increase enzyme production in term of yield and quality. Beta- glucosidases - a derivative of linamarase from microorganisms can be more effective in detoxification of cyanogenic glycosides present in some plants [7]. The objectives of the study targeted the mechanism action of purified linamarase from Lb. plantarum for detoxification of linamarin present in cassava peels for industrial use.

\section{Materials and Methods}

\section{Bacterial isolate}

The bacterial isolate employed in this study was isolated from fermented cassava peels. The fermentation process was carried out for 96 hours in the Microbiology laboratory, Federal University of Technology, Akure, Nigeria. The fermentation of cassava peels account for the different bacteria isolated under cultural condition at room temperature.

\section{Linamarase assay}

Linamarase activity was assayed from the supernatant collected at the end of cold centrifugation using spectrophotometer (Laboratory Technology Digital Colorimeter). Linamarase activity was assay in the reaction mixture containing $0.5 \mathrm{~mL}$ of $50 \mathrm{mM}$ potassium phosphate buffer $\mathrm{pH} 6.0$ and $0.5 \mathrm{ml}$ precipitate of the crude extract containing substrate, incubated at $37^{\circ} \mathrm{C}$ for 15 minutes and measured at $540 \mathrm{~nm}$ wave lengths [8]. One unit of linamarase activity was defined as amount of enzyme producing 1 micromole of para-nitrophenol per minute under the experimental conditions as stipulated by Olaniyi et al. [8].

\section{Protein determination}

The protein estimation of the crude extract was determined by Bradford method and Bovine Serum Albumin (BSA) was used as standard [9].
J Bacteriol Mycol - Volume 4 Issue 1 - 2017

ISSN : 2471-0172 | www.austinpublishing group.com

Adeleke et al. (C) All rights are reserved
Citation: Adeleke BS, Akinyele BJ and Olaniyi OO. Purification and Characterization of Linamarase from Lactobacillus Plantarum. J Bacteriol Mycol. 2017; 4(1): 1045. 
Table 1: Summary of linamarase purification.

\begin{tabular}{|c|c|c|c|c|c|c|c|c|}
\hline Step & Vol. & PC & EA & TP & TA & SPA & Yield & Fold \\
\hline Crude Enzyme & 500 & 37.95 & 56.28 & 18975 & 28140 & 1.48 & 100 & 1 \\
\hline $\begin{array}{c}\text { Ammonium } \\
\text { sulphate } \\
\text { precipitation }\end{array}$ & 100 & 35.68 & 73.49 & 3568 & 7349 & 2.06 & 15.45 & 1.39 \\
$\begin{array}{c}\text { lon exchange } \\
\text { Chromatography }\end{array}$ & 45 & 6.81 & 212.36 & 306.45 & 9556.20 & 31.18 & 33.96 & 21.03 \\
\hline Gel & 33 & 5.50 & 239.65 & 181.50 & 7908.45 & 43.57 & 28.10 & 29.38 \\
\hline
\end{tabular}

Key: PC: Protein Content $(\mathrm{mg} / \mathrm{mL})$; SPA: Specific Activity $(\mu \mathrm{mol} / \mathrm{min} / \mathrm{mg})$; EA Enzyme Activity $(\mu \mathrm{mol} / \mathrm{min} / \mathrm{mg})$; TA: Total Activity $(\mu \mathrm{mol} / \mathrm{min} / \mathrm{mL}) ;$ TP: Total Protein (mg).

\section{Linamarase purification}

The supernatant obtained after centrifugation was purified in three stages. In stage one, $100 \mathrm{~mL}$ of the supernatant of crude linamarase obtained from the cold centrifugation was precipitated by adding $571 \mathrm{~g}$ ammonium sulphate to obtained $70 \%$ ammonium sulphate concentration. After cold centrifugation at 6000rpm for 30 minutes, the precipitate obtained was diluted in $100 \mathrm{ml}$ phosphate buffer ( $\mathrm{pH}$ 6.0) and then dialyzed in the same buffer system. In stage two, the partially purified linamarase obtained after dialysis was purified on ion exchange column chromatography containing DEAE (diethylamineethyl) Sephadex A-50 (2.0 x $2.5 \mathrm{~cm}$, Pharmacia). The eluates of the partially purified linamarase obtained from stage two were washed with $300 \mathrm{~mL}$ ion-free water, followed by $200 \mathrm{~mL}$ $0.01 \mathrm{M}$ Tris- $\mathrm{HCl}$ buffer $\mathrm{pH}$ 8.0. The gel was eluted with $\mathrm{NaCl}$. The absorbance of each of the fraction was measured. In stage three, $2.5 \mathrm{~mL}$ of partially purified linamarase was loaded onto a column chromatography (2.5 in diameter and $30 \mathrm{~cm}$ high) using Sephadex G-150 (Pharmacia). Phosphate elution buffer at $50 \mathrm{mM} \mathrm{pH} 6.0$ was applied with the flow rate $20 \mathrm{ml} / \mathrm{hr}$. A fraction of $5.0 \mathrm{~mL}$ was collected at interval of 30 minutes and the highest linamarase activity was determined with Para nitrophenyl $\beta$-D glucosides as a substrate, at $280 \mathrm{~nm}$ (Jenwey 6305). Fractions with linamarase activity were pooled and concentrated in glycerol solution at $30^{\circ} \mathrm{C}[10,11]$.

\section{Characterization of Purified Linamarase}

\section{Effect of pH on linamarase activity}

Different buffer system $50 \mathrm{mM}$ of Glycine- $\mathrm{HCl}, \mathrm{pH} 3.0$, acetate buffer $\mathrm{pH}$ 4.0, phosphate buffer $\mathrm{pH}$ 6.0, Tris- $\mathrm{HCl} \mathrm{pH} 8.0$ were prepared. Each of this buffer solution was used to prepare 1\% Para nitrophenyl $\beta$-D glucosides solution used as substrate in assaying the enzyme. The assay was carried out according to the standard assay procedure [11].

\section{Effect of pH stability on linamarase}

To observe the $\mathrm{pH}$ stability, the purified enzyme was kept in different $\mathrm{pH}$ buffers ranged from 4.0 to 12.0 at room temperature for different time interval up to 2 hours. Thereafter, relative linamarase activity was assay.

\section{Effect of temperature on linamarase activity and stability}

Linamarase activity was assay by incubating the enzyme reaction mixture at different temperature, 10 to $100^{\circ} \mathrm{C}$ for 30 minutes. Thermostability of the enzyme was also determined. Samples were collected at 10 minutes and thereafter residual activities were evaluated under standard assay conditions.

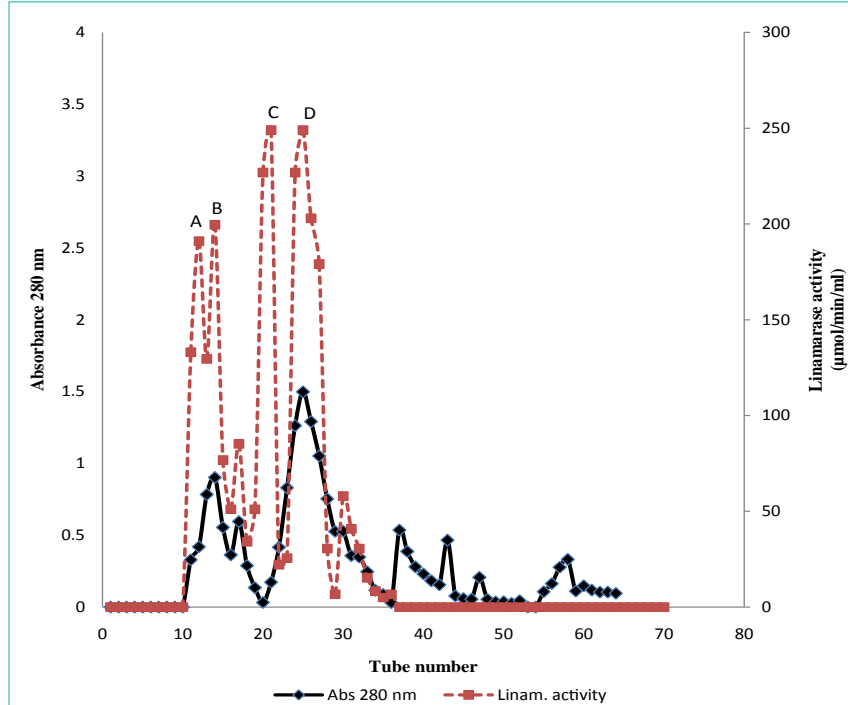

Figure 1: Elution profile of crude linamarase on DEAE Sephadex A-50.

\section{Effect of substrate concentration}

The effect of substrate concentration $[S]$ on the rate of enzyme action was studied. The substrate concentration $[\mathrm{S}]$ value ranged from $0.25 \mathrm{mg} / \mathrm{mL}$ to $10.00 \mathrm{mg} / \mathrm{ml}$. The Lineweaver-Burk plot was made to determine the maximum velocity $(\mathrm{Vmax})$ and Michaelis-Menten constant $(\mathrm{Km})$. Both the maximum velocity (Vmax) and MichaelisMenten constant $(\mathrm{Km})$ of the enzyme were calculated.

\section{Effect of metal ions on linamarase activity}

A stock solution of $10 \mathrm{mM}$ for different metal (Ca, Mg, $\mathrm{Zn}, \mathrm{Fe}$ and $\mathrm{Cu}$ ) ions was prepared. Two milliliters of the prepared solution was mixed with $2 \mathrm{ml}$ of enzyme solution. The mixture was incubated for 5 minutes at room temperature. Zero point five milliliters $(0.5 \mathrm{~mL})$ of the mixture were collected and linamarase assay was carried out according to the standard assay procedure.

\section{Results and Discussions}

\section{Summary of purification}

Table 1 shows thelinamarasepurification processes. Thelinamarase purification was obtained in three steps with approximately total protein recovery of $29 \%$ and $43.57 \mu \mathrm{mol} / \mathrm{min} / \mathrm{mg}$ specific activity. The elution pattern of the linamarase enzyme on Sephadex A-50 gel filtration chromatography is shown in Figure 1. Linamarase activity was detected in fraction tubes 10.00 to 36.00 . The fractionation tubes with linamarase activity were pooled and further purified on Sephadex G-150 (Figure 2). The variation in the linamarase activity peaks might be due to the rate of elution and surrounding conditions [12].

\section{Characterization of linamarase}

Effect of temperature on linamarase acivity and stability: The effect of temperature on linamarase activity and stability is shown in Figures 3 and 4 . The linamarase activity increased with increase in incubation temperature until an optimum percentage relative activity was reached at $50^{\circ} \mathrm{C}$ (Figure 3). An increase in temperature beyond the optimum has been reported to disrupt the enzyme structure and loss of activity. The result obtained from this 


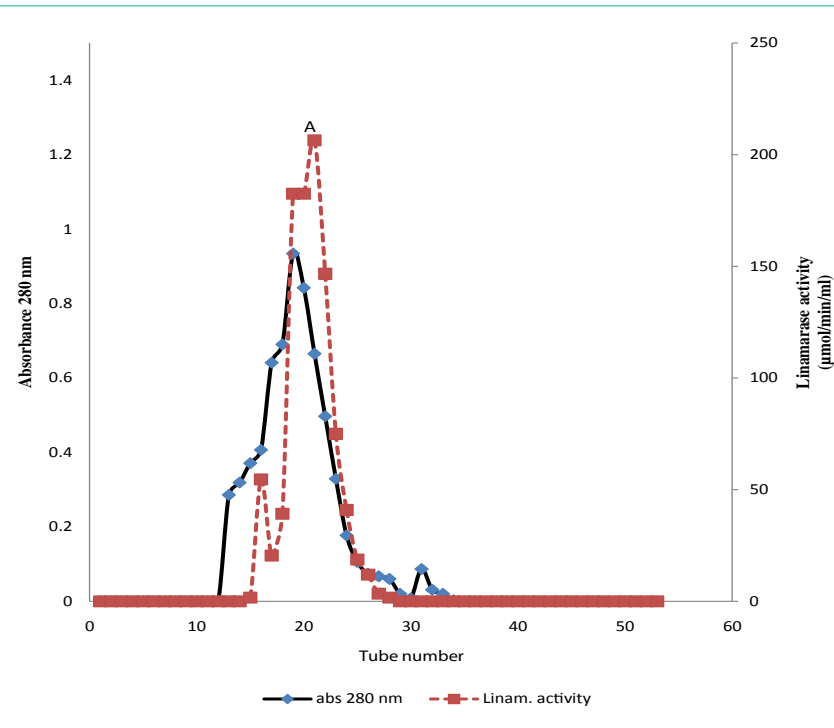

Figure 2: Elution profile of partially purified linamarase on Sephadex G-150.

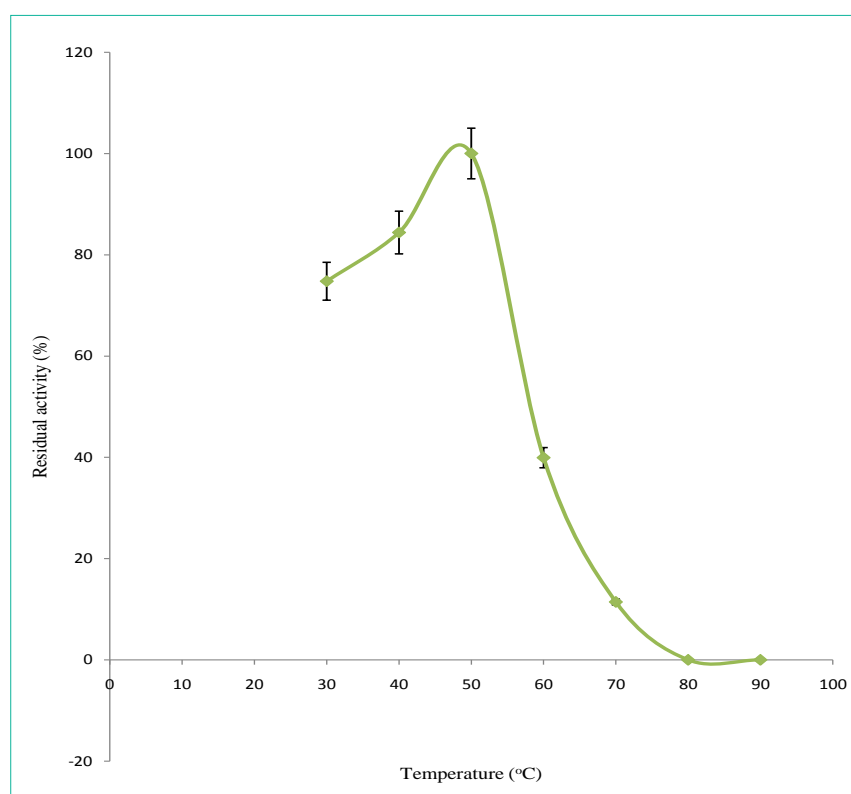

Figure 3: Effect of temperature on purified linamarase activity.

study was in agreement with the findings of Ogbonaya and Florence [13] who reported temperature $50^{\circ} \mathrm{C}$ for linamarase activity from Lactobacillus delbrueckii NNRL B-763.

The linamarase activity has the highest relatively temperature stability at $40^{\circ} \mathrm{C}$ between 20 and 40 minutes before a slight decline in its activity was observed. The linamarase activity has the lowest temperature stability at $80^{\circ} \mathrm{C}$ between 40 and 60 minutes (Figure 4). The enzymatic activity gradually decrease with increase in temperature. The result obtained was similar to the findings of Gueguen et al. [14] who reported optimum stability 40 and $50^{\circ} \mathrm{C}$ of $\beta$-glucosidase from Leuconostoc mesenteroides.

Effect of substrate concentration: The Michaelis constant $(\mathrm{Km})$ indicated the concentration of substrate to fill the half active sites of an enzyme. It is also the measure of strength of the Enzyme-

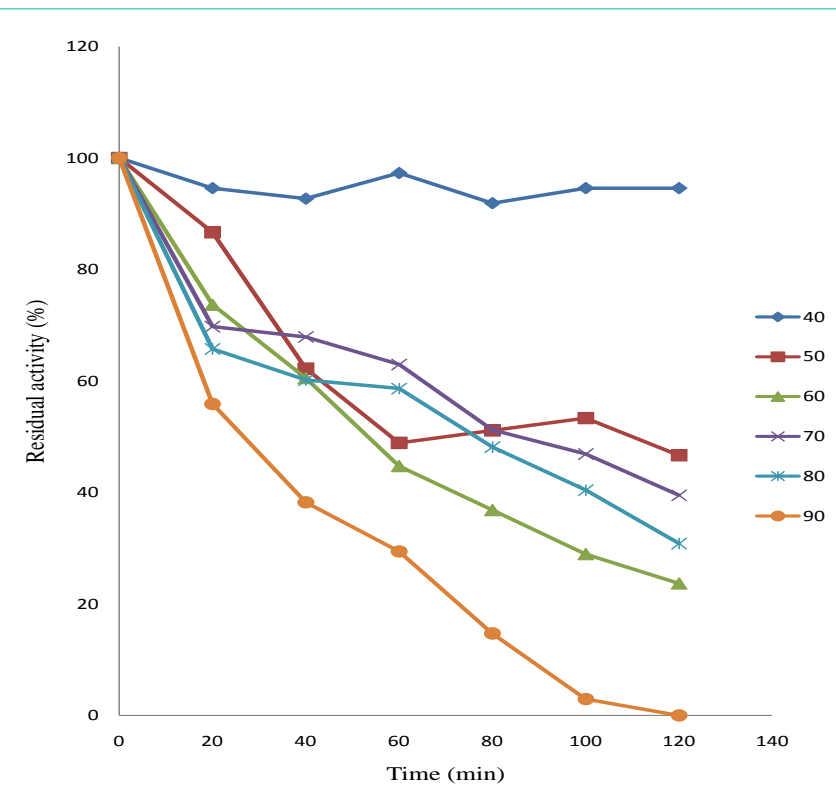

Figure 4: Thermostability profile of purified linamarase.

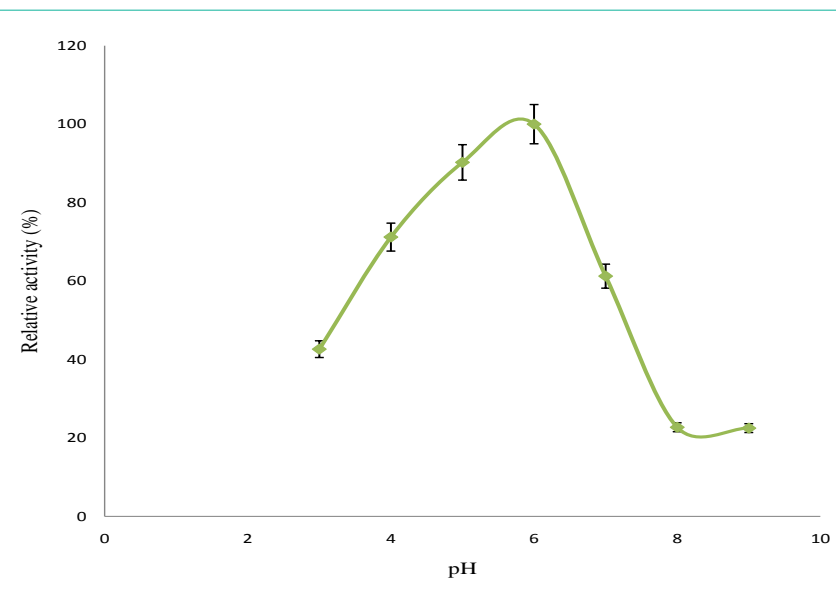

Figure 5: Effect of $\mathrm{pH}$ on purified linamarase activity.

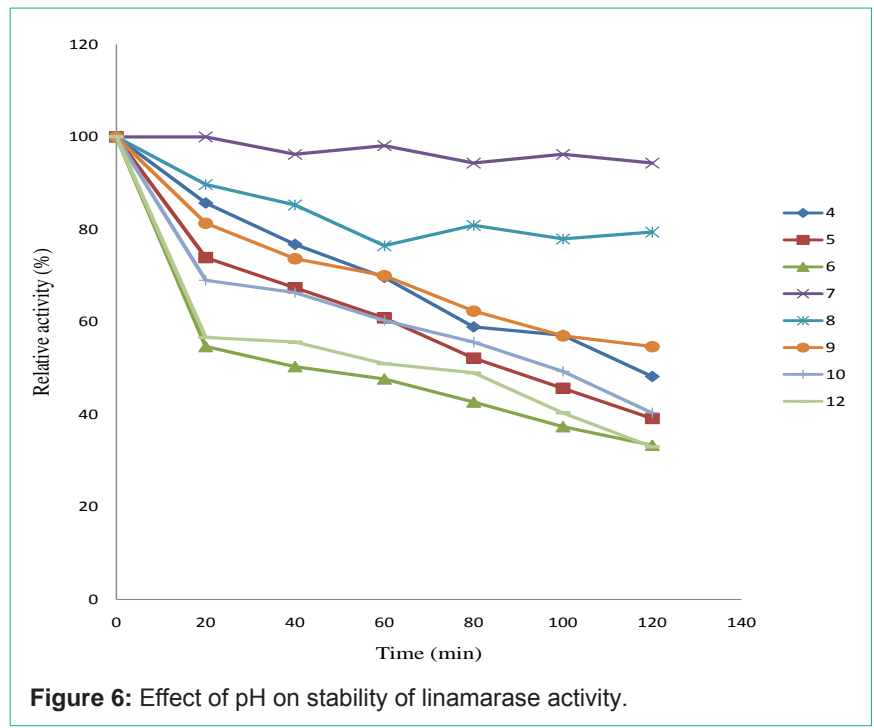




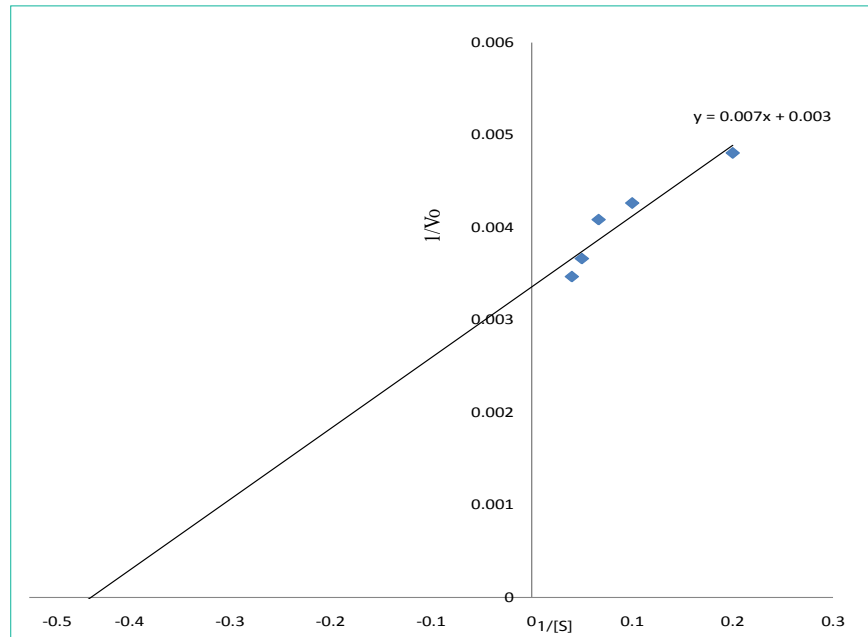

Figure 7: Line Weaver-Bulk double reciprocal plot $(\mathrm{Km}=2.27) \mathrm{mg} / \mathrm{mL}, \mathrm{Vmax}=$ $294.12 \mu \mathrm{mol} / \mathrm{min} / \mathrm{mL})$.

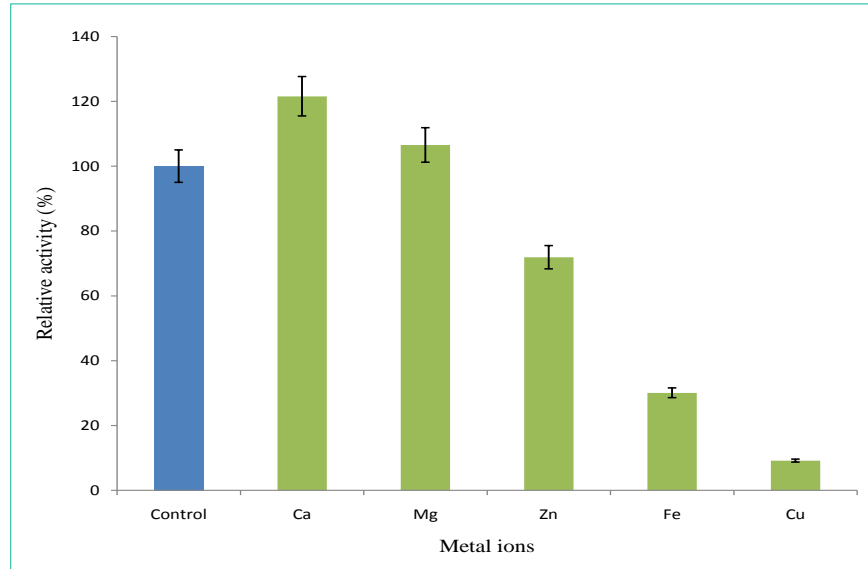

Figure 8: Effect of metal ions on linamarase activity.

Substrate (ES) complex. The result obtained from this study showed higher substrate concentration. The purified linamaras exhibited $\mathrm{Km}$ value $2.27 \mathrm{mg} / \mathrm{mL}$ and maximum velocity (Vmax) was $294.12 \mu \mathrm{mol} /$ $\mathrm{min} / \mathrm{mL}$ (Figure 7). Akinyele et al. [16] reported that high Km value indicates weak binding of the enzyme- substrate and vice versa. Therefore, linamarase with high $\mathrm{Km}$ value might have less affinity to the substrates [17].

Effect of metal ions on linamarase activity: The concentration of metal ions used in this study exerts their effect on linamarase activity (Figure 8). The metal ions exerted activation and inhibition on the linamarase activity. The linamarase activity was stimulated by $\mathrm{Ca}$ and $\mathrm{Mg}$ ions correspondingly, while $\mathrm{Cu}, \mathrm{Zn}$ and $\mathrm{Fe}$ ions exhibited varied degree of inhibition on linamarase activity.

\section{Conclusion}

The results obtained from this study revealed that purified linamarase was active over a wide range of $\mathrm{pH}$ and moderate temperature. Its stability suggests its utilization on introduction during fermentation of cassava peels for total detoxification process based on lactic acid fermentation in food industry where extreme conditions are required.

\section{References}

1. Yessoufou A, Ategbo JM, Girard A, Prost J, Dramane KL, Moutairou K, et al Cassava-enriched diet is not diabetogenic rather it aggravates diabetes in rats. Fundamental Clinical Pharmacology. 2002; 20: 579-586.

2. Nzwalo H, Cliff J. Konzo: from poverty, cassava and cyanigen intake to toxic nutritional neurological diseases. Tropical Disease. 2011; 5: 1051-1371.

3. Adetunji AR, Isadare DA, Akinluwade KJ, Adewoye OO. Waste-to-wealth applications of cassava: A review study of industrial and agricultural applications. Advances in Research. 2015; 4: 212-229.

4. Azam-Ali S, Judge E, Fellows P, Battcock M. Small-scale food processing. A directory of equipment and methods. $2^{\text {nd }}$ Edition. ITDG Publishing. 2003.

5. Nwokoro O, Anya FO. Linamarase enzyme from Lactobacillus delbrueckii NRRL B-763: Purification and some properties of a $\beta$-glucosidase. Journal of Mexican Chemistry and Sociology. 2011; 55: 246-250.

6. Nok JN, Ikediobi CO. Some properties of linamarase from cassava (Manihot esculenta Crantz) cortex. Journal of Food Biochemistry. 1999; 14: 477-489.

7. Julius $\mathrm{KI}$, Charles $\mathrm{CA}$, James $\mathrm{OA}$. Kinetic activity of commercial native linamarase (CNLIN) and engineered ( $\beta$-glucosidase) from Saccharomyces cerevisiae on cassava linamarin. Advanced Journal of Food Science and Technology. 2014; 6: 149-154.

8. Ogundu EC, Okoh PN, Ikediobi CO. Enzyme-Substrate specificity of $\beta$ $D$-glucosidase from fungal, bacterial and cassava sources using p-nitrophenol $\beta$-D-glucoside and cassava linamarin as substrates. Nature and Science. 2014; 12: 162-167.

9. Bradford MM. A rapid and sensitive method for the quantitation of microgram quantities of protein utilizing the principle of protein-dye binding. Analytical Biochemistry. 1976; 72: 248-254.

10. Hammami I, Siala R, Jridi M, Ktari N, Nasri M, Mohamedali T. Partial purification and characterization of chil O8, a novel antifungal chitinase produced by Bacillus cereus. Journal of Applied Microbiology. 2013; 115: 358-366.

11. Olaniyi OO, Arotupin DJ, Akinyele BJ, Bamidele OS. Kinetics properties of purified $\beta$-mannanase from Penicillim itaculum. British Microbiology Research Journal. 2014; 2: 1092-1104.

12. Olaniyi OO, Igbe FO, Ekundayo TC. Optimization studies on mannanase production by Trichosporonoides oedocephalis in submerged state fermentation. E3 Journal Biotechnology. 2013; 4: 110-116.

13. Ogbonnaya N, Florence OA. Linamarase enzyme from Lactobacillus delbrueckii NRRL B-763: purification and some properties of a $\beta$-Glucosidase. Journal of Mexican Chemistry and Sociology. 2011; 55: 246-250.

14. Gueguen Y, Chemardin P, Labrot P, Arnaud A, Galzy PJ. Purification and characterization of an intracellular $\beta$-glucosidase from a new strain of Leuconostoc mesenteroides isolated from cassava. Applied Journal of Microbiology. 1997; 82: 469-476.

15. Brauman A, Keleke S, Malonga M, Miambi E, Ampe F. Microbiological and biochemical characterization of cassava retting, traditional lactic acid fermentation for foo-foo (cassava flour) production. Applied Environmental Microbiology. 1996; 62: 854-858.

16. Akinyele BJ, Olaniyi OO, Adetunji CO. Screening and optimization of nutritional conditions for mannanase production by Penicillium italicum LAD-A5 in solid state fermentation. E3 Journal of Biotechnology and Pharmaceutical Reasearch. 2013; 4: 35-41.

17. José MP, Barbosa RL, Souza C, Moura de Melo AT, Fricks CMF, et al. Biochemical characterization of lipase from a new strain of Bacillus sp. ITP001. Quim. Nova. 2012; 35: 1173-1178. 